\title{
Project Risk Patterns: A Comparison Across Three Periods
}

\author{
Fachrurrazi", Saiful Husin" Mahmuddin"

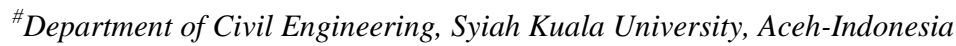 \\ E-mail: fachrurrazi@unsyiah.ac.id
}

\begin{abstract}
Aceh has experienced the critical event in three periods (political conflict, tsunami disaster, regular period) which they are different in risk characteristics. These critical events have inflicted on the sectors of life, including the construction sector. Some risk variables have been identified from previous studies that will be applied and analysis in this area by using risk assessment theory. In this research, we focus on the project risks in the three periods that it has an impact on the loss of profit on the contractors in Aceh. The potential risk variable and its pattern will be analyzed crossover in all the three periods. Qualitative risk analysis is used to describe the project risk of contractors who have conduct project in those periods. The potential risk variable, unofficial levies charges by bullies (P11), is the most extreme than other risks variables in the 1st period, has decreased in subsequent periods (2nd period and third period). The risk variable of $P 11$ is the most avoided by the contractor because it is very influential on the achievement of the project objectives. This P11 variable not only emerged during the political conflict period but also in the posttsunami period due to social, economic factors, although it has decreased. This P11 variable not only affects the risk singly but also could trigger the other variable, thus providing a double effect on project risks, such as increased costs for safety and security in project areas (P5) and Increased labor costs due to increased wages (P6). The result of risk analysis using qualitative risk analysis method with Risk Important Index (RII) shows that risk variable of P1 (Bureaucratic of the owner delays payment terms), P12 (Contractors shortage of funds caused by the cost overrun on the project), has experienced decreasing from 2 nd period to 3 rd period. However, the hypothesis results show that the decreasing is not significant. It indicates that this test is critical to include in risk analysis, especially on the method of qualitative risk analysis.
\end{abstract}

Keywords - risk assessments; contractors; hypothesis; the three critical periods; unofficial levies charges by bullies; frequency index; severity index; important index; risk matrix; risk pattern; Aceh.

\section{INTRODUCTION}

The potential risks that will affect the organization's objectives should be evaluated sustainable over the time and be compared mainly to the work area of the organization; this is done to optimize the output of the organization's objectives. The Contractors who have three primary goals as triple constraints (cost, quality and time) [1], need to assess the risk to maximize their goals. Risk management only needs to be addressed at the vital risk, without having to spend time and effort on less essential risks. Therefore, this study will focus on the critical risks that have some impacts on the profit loss, especially the contractors who have conducted the project in Aceh.

Aceh has experienced in three unique contexts of risk throughout its history [2], namely the political conflict (1st Period) in 1998-2003[18], post-tsunami disaster (2nd Period) in 2005-2009 [2], and post-mitigation (3rd Period) in 2010 present. These periods have a difference in the risk characteristics that have an impact on the achievement of project goal [2]. During the political conflict period (1st Period), it has raised awareness for investors, contractors in outside of Aceh, who feel unsafe to invest due to the high level of risk during that period [2]. The political conflict has been greatly reduced after Aceh experienced the tsunami on December 26, 2004. The disaster caused the economy government and other sectors to be paralyzed entirely [2]. The considerable attention of outsiders to restore the system in Aceh has created enormous project work, especially in the construction sector. The enormous amount of work on the one hand and the limited resources, on the other hand, has created different characteristic of risk from the previous period [2]. This 2nd period has ended after six years. In 2010, Aceh has entered a reasonable period. The question here is whether the project risks have decreased drastically or otherwise. To what extent is the decrease of risks? This research will focus to discuss the principal risks variables of the project on three periods in Aceh.

The research aims are to assess the risk and to identify the risk pattern in all three periods in Aceh, which causes the loss of profit on contractors. To achieve these aims, a dataset has been prepared from the 15 contractors with the significant qualification that has been carrying out projects in the third periods and domiciled in the Aceh. Qualitative risk assessment theory, i.e., the risk matrix method, that 
combining the parameters of both frequency and severity will be used to analyze the risk. It is a rapid qualitative approach to assigning a scale, for example, Low, medium, high, and extreme.

Assessing risk in the context of the project in the three periods that has a difference in the risk pattern is very important. Some of the risk variables could occur in different periods and triggered by the different threat. The potential risk variable, such unofficial levy charge (P11) is in fir $^{\text {st }}$ period is caused by political aspect, and social aspect causes the 2 nd period. This variable in addition to posing a very high risk, it can also trigger other variables in contributing to increased risk levels, such as variable of P11 could trigger the variable of P5 and P6.

In this research, we are using hypothesis test that has a role in the risk outcome, rather than using analysis of RII only. This finding shows that statistical tests are essential in qualitative risk analysis. It is due to the data variation of the respondents is worth considering, which is not just enough by the statistics mean of RII only as in P1, P4, and P12. This study is different from other studies; it includes statistical tests affecting the results of qualitative risk assessment.

\section{MATERIAL AND METHODS}

This section will describe the method to achieve the research aims, which comprises the research object, data sources, data collecting and the data analysis. Steps have developed research, as follows:

1. The hypothesis development;

2. Several methods for identifying risk variables, such as fishbone diagram analysis, can be used. In this research, we list the literature review to apply in risk in Aceh, as shown in Table I;

3. Validation and reliability, successfully as shown in Table II, Table III;

4. Statistic descriptive analysis, as shown in Table IV;

5. Qualitative Risk Analysis (QRA) is a risk assessment that uses a tabulation approach for the potential number of events (Risk Frequency), the potential magnitude of the impact of the event (Risk Severity), and the potential level of importance (Risk Important) which can occur due to threats and vulnerabilities. QRA is rated on a quality scale, such as Low, Medium, High, and Extreme.

1. Analysis of Frequency Index (FI) and Severity Index (SI), Risk Important Index (RII) analysis, and Risk rank, as shown in Table V;

2. Risk rating, as shown in Table V;

3. moreover, Qualitative Risk assessment based on risk matrix analysis, as shown in Table X;

6. Hypothesis testing for each variable across the three periods is using ANOVA, as shown in Table XI;

7. Risk Pattern is as shown in Fig.1, Fig.2, and Fig.3.

\section{A. Hypothesis}

Based on the variables that have been prepared in this study to analyze risk, our hypothesis is. Unofficial levies charges by bullies (P11) is the most dominant and characteristic variable at the 1 st period. These variables have experienced a significant decrease in the next period (2nd Period and third period). In this study, we will test the P11 at first period against other periods.

Ho: $\mu_{\mathrm{P} 11 \text { in the } 1 \text { st period }}>\mu_{\mathrm{P} 11 \text { in another period }}$

Hi: $\mu_{\mathrm{P} 11 \text { in the 1st period }} \leq \mu_{\mathrm{P} 11 \text { in another period }}$

\section{B. The Risks Variable}

This risks variable, which was collected from some literature, are 25 variables, as shown in Table I.

TABLE I

IDENTIFICATION OF THE RISK VARIABLES

\begin{tabular}{|c|c|c|}
\hline Code & Risk Variable & Literature \\
\hline P1 & $\begin{array}{l}\text { Bureaucratic of owner delays payment } \\
\text { terms }\end{array}$ & [3], [ 5] \\
\hline $\mathrm{P} 2$ & Inaccuracies in the cost estimation & [5], [6] \\
\hline P3 & Overhead costs that exceed forecasts & [5], [6] \\
\hline P4 & Penalties for project delays & [3], [5] \\
\hline P5 & $\begin{array}{l}\text { Increased costs for safety and security in } \\
\text { project areas }\end{array}$ & [3], [5] \\
\hline P6 & $\begin{array}{l}\text { Increased labor costs due to increased } \\
\text { wages }\end{array}$ & [7], [8] \\
\hline P7 & Budgeting inefficient/wasteful & [3], [4] \\
\hline P8 & Cash-flow at the project site is very less & {$[3],[5]$} \\
\hline P9 & $\begin{array}{l}\text { The interest rate of the project Financing } \\
\text { (debtor), bank / third party, is very high }\end{array}$ & [3] \\
\hline P10 & Target profit/margin that is too low & [3] \\
\hline P11 & Unofficial levies charges by bullies & [3], [5] \\
\hline P12 & $\begin{array}{l}\text { Contractors shortage of funds caused by } \\
\text { the cost overrun on the project }\end{array}$ & [3], [4] \\
\hline $\mathrm{P} 13$ & Investors or funders bankruptcy & [3] \\
\hline P14 & $\begin{array}{l}\text { expenditure does not match toward the } \\
\text { progress of work }\end{array}$ & [3] \\
\hline P15 & Using improper construction methods & [3], [5] \\
\hline P16 & $\begin{array}{l}\text { New technologies, especially did not know } \\
\text { how to use properly }\end{array}$ & [5] \\
\hline P17 & $\begin{array}{l}\text { The demand for replacement construction } \\
\text { methods }\end{array}$ & - \\
\hline P18 & $\begin{array}{l}\text { Technical specifications are not } \\
\text { appropriate or incomplete }\end{array}$ & [4] \\
\hline P19 & $\begin{array}{l}\text { Contract change orders arising from the } \\
\text { measurement results and field } \\
\text { investigations }\end{array}$ & [4] \\
\hline $\mathrm{P} 20$ & $\begin{array}{l}\text { Design construction methods inefficient } \\
\text { and less effective }\end{array}$ & [3] \\
\hline P21 & $\begin{array}{l}\text { Construction technology is insufficient } \\
\text { availability in the market }\end{array}$ & [3], [4] \\
\hline $\mathrm{P} 22$ & quality control and testing of inadequate & [5] \\
\hline P23 & $\begin{array}{l}\text { The damage to the building around the } \\
\text { project due to the project }\end{array}$ & [3] \\
\hline $\mathrm{P} 24$ & Problems on the project feasibility & [3] \\
\hline $\mathrm{P} 25$ & $\begin{array}{l}\text { Misreporting lab report that led to the } \\
\text { contractor received a claim from the owner }\end{array}$ & - \\
\hline
\end{tabular}

\section{Target Groups (Respondents)}

Project risk and its components are strongly influenced by individual and social perceptions or even by groups of psychologists, politicians, scientists, sociologists, and economists. They had generated theories to explain how risk characteristics at the level culture of individual, group or social affecting the risk understanding [10].

The target respondents in this research, especially someones that supplying information for a survey, are director of the fifteen contractors with exceptional 
qualifications, and they have ever conducted the contracts on the three periods in Aceh.

\section{Validity and Reliability}

The validity and reliability test is used to measuring the success of research. Assessment instruments must be both reliable and valid for study results to be credible and must be examined and reported for each instrument. Both validity and reliability of questionnaires for measuring the frequencies have been conducted in previous studies. Meanwhile, validity and reliability of questioner for measuring the severity are shown in Table II and Table III. The validity of an item are following:

if $r_{x y}>r_{s i g}$ then the item is significantly correlated to the total score (declared valid)

if $r_{x y}<r_{s i g}$ then the item is not correlated to the total score (declared invalid)

TABLE II

VALIDITY TEST OF THE RISK VARIABLE ITEM (RSIG. $=0.553)$

\begin{tabular}{|c|c|c|c|c|c|c|}
\hline \multirow{2}{*}{$\begin{array}{c}\text { Variable } \\
\text { of Risk }\end{array}$} & \multicolumn{6}{|c|}{ Three critical periods of Aceh province } \\
\cline { 2 - 7 } & $\mathbf{1 s t}$ Period & \multicolumn{2}{|c|}{ 2nd Period } & \multicolumn{2}{c|}{ 3rd Period } \\
\hline & r & Indic. & r & Indic. & r & Indic. \\
\hline P1 & 0.7170 & Valid & 0.5750 & Valid & 0.9620 & Valid \\
\hline P2 & 0.8740 & Valid & 0.8900 & Valid & 0.8820 & Valid \\
\hline P3 & 0.9030 & Valid & 0.9590 & Valid & 0.9540 & Valid \\
\hline P4 & 0.9600 & Valid & 0.9000 & Valid & 0.9200 & Valid \\
\hline P5 & 0.5980 & Valid & 0.8280 & Valid & 0.9450 & Valid \\
\hline P6 & 0.5340 & Valid & 0.5400 & Valid & 0.6320 & Valid \\
\hline P7 & 0.9550 & Valid & 0.9740 & Valid & 0.9860 & Valid \\
\hline P8 & 0.7660 & Valid & 0.8530 & Valid & 0.8430 & Valid \\
\hline P9 & 0.7680 & Valid & 0.7840 & Valid & 0.8040 & Valid \\
\hline P10 & 0.7250 & Valid & 0.7470 & Valid & 0.7690 & Valid \\
\hline P11 & 0.6300 & Valid & 0.5540 & Valid & 0.6390 & Valid \\
\hline P12 & 0.7100 & Valid & 0.6340 & Valid & 0.8580 & Valid \\
\hline P13 & 0.9420 & Valid & 0.9740 & Valid & 0.9450 & Valid \\
\hline P14 & 0.9690 & Valid & 0.9830 & Valid & 0.9670 & Valid \\
\hline P15 & 0.9220 & Valid & 0.9520 & Valid & 0.9200 & Valid \\
\hline P16 & 0.9300 & Valid & 0.9390 & Valid & 0.7950 & Valid \\
\hline P17 & 0.5930 & Valid & 0.6130 & Valid & 0.6280 & Valid \\
\hline P18 & 0.9160 & Valid & 0.9490 & Valid & 0.9410 & Valid \\
\hline P19 & 0.6260 & Valid & 0.5800 & Valid & 0.5780 & Valid \\
\hline P20 & 0.6140 & Valid & 0.6610 & Valid & 0.5710 & Valid \\
\hline P21 & 0.6160 & Valid & 0.7330 & Valid & 0.8450 & Valid \\
\hline P22 & 0.9560 & Valid & 0.9150 & Valid & 0.8740 & Valid \\
\hline P23 & 0.7320 & Valid & 0.7380 & Valid & 0.6500 & Valid \\
\hline P24 & 0.7830 & Valid & 0.8030 & Valid & 0.7180 & Valid \\
\hline P25 & 0.9370 & Valid & 0.9590 & Valid & 0.9620 & Valid \\
\hline
\end{tabular}

The product moment correlation using the formula as follows [11]:

$$
\mathrm{r}_{\mathrm{xy}}=\frac{\mathrm{n} \sum\left(\mathrm{x}_{\mathrm{i}} \mathrm{y}_{\mathrm{i}}\right)-\sum \mathrm{x}_{\mathrm{i}} \sum \mathrm{y}_{\mathrm{i}}}{\sqrt{\left\{\mathrm{n} \sum \mathrm{x}_{\mathrm{i}}^{2}-\left(\sum \mathrm{x}_{\mathrm{i}}\right)^{2}\right\}\left\{\mathrm{n} \sum \mathrm{y}_{\mathrm{i}}^{2}-\left(\sum \mathrm{y}_{\mathrm{i}}\right)^{2}\right\}}}
$$

Where $r_{x y}$ is correlation coefficients, $\mathrm{x}_{\mathrm{i}}$ is a score of item-i, $y_{i}$ is total score of item $i$, and $n=$ total number of respondents. Validation test as shown in Table II.

Reliability, which uses the internal consistency estimate, is to conclude in generally the value of each item with an overall score and generally use analysis Cronbach Alpha (CAlpha). The reliability score is using the coefficient $\mathrm{C}$ Alpha should be $\geq 0.8$ (which is a value to the appropriateness of the questionnaires). The formula used is as follows [11]:

$$
\alpha=\frac{\mathrm{k}}{(\mathrm{k}-1)}\left[1-\frac{\sum_{\mathrm{i}=1}^{\mathrm{k}} \sigma^{2} \mathrm{yi}}{\sigma^{2} \mathrm{x}}\right]
$$

Where: $\mathrm{k}$ is the number of scale items; $\sigma^{2}$ yi is the variance of item- $i ; \sigma^{2}{ }_{\mathrm{x}}$ Is the variance of the observed total scores. The validity of the variables which are based on the data from 15 respondents are using a significance level of 5\% $\left(r_{\text {sig }}=0.553\right)$, the result of reliability, as shown in Table III.

TABLE III

RESUlt OF RELIABILITY TEST FOR QUESTIONER INSTRUMENT

\begin{tabular}{|c|l|c|c|c|}
\hline \multirow{2}{*}{ No } & \multirow{2}{*}{$\begin{array}{c}\text { Questioner } \\
\text { for Period }\end{array}$} & $\begin{array}{c}|c| \\
\text { Cronbults of Questioner } \\
\boldsymbol{\alpha}\end{array}$ & Reliability & Indication \\
\hline 1 & 1st Period & 0.6 & 0.9732 & Reliable \\
\hline 2 & 2nd Period & 0.6 & 0.9702 & Reliable \\
\hline 3 & 3rd Period & 0.6 & 0.9768 & Reliable \\
\hline
\end{tabular}

\section{RESULT AND DISCUSSION}

\section{A. Descriptive Analysis of Data}

TABLE IV

\begin{tabular}{|c|c|c|c|c|c|c|c|c|c|c|c|c|}
\hline \multirow{4}{*}{ 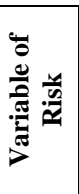 } & \multicolumn{12}{|c|}{ Mean and Standard Dev. of each Risk Variables } \\
\hline & \multicolumn{6}{|c|}{ Frequency of Risk } & \multicolumn{6}{|c|}{ Severity of Risk } \\
\hline & \multicolumn{2}{|c|}{ 1st Period } & \multicolumn{2}{|c|}{$\begin{array}{c}\text { 2nd } \\
\text { Period }\end{array}$} & \multicolumn{2}{|c|}{$\begin{array}{c}\text { 3rd } \\
\text { Period }\end{array}$} & \multicolumn{2}{|c|}{ 1st Period } & \multicolumn{2}{|c|}{$\begin{array}{c}\text { 2nd } \\
\text { Period }\end{array}$} & \multicolumn{2}{|c|}{$\begin{array}{c}\text { 3rd } \\
\text { Period }\end{array}$} \\
\hline & $\mu$ & $\boldsymbol{\sigma}$ & 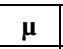 & 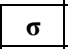 & 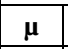 & $\sigma$ & $\mu$ & $\pi$ & 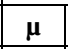 & 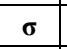 & $\mu$ & $\sigma$ \\
\hline $\mathrm{P} 1$ & 2.27 & 1.22 & & 1.58 & 80 & 1.26 & 2.67 & 1.18 & 2.67 & 1.18 & 2.73 & 1.33 \\
\hline $\mathrm{P} 2$ & 73 & 03 & & 15 & & 1.15 & 47 & & 40 & & 2.40 & \\
\hline 15 & & 37 & & 49 & & 41 & & & 27 & & .47 & 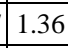 \\
\hline $\mathrm{P} 4$ & 93 & .28 & & 1.19 & 2.00 & 1.36 & 2.33 & 1.50 & 2.27 & 44 & 2.33 & 1.50 \\
\hline P5 & ) & 20 & & 9 & & 13 & & & 80 & & 2.87 & 25 \\
\hline P6 & 81 & 46 & 80 & 1.37 & 27 & 1.28 & 2.73 & 1.39 & 2.47 & 1.25 & 2.53 & 1.3 \\
\hline P7 & 67 & .18 & 67 & 1.18 & \begin{tabular}{|l|}
1.73 \\
\end{tabular} & 1.28 & 1.87 & 41 & 1.80 & 42 & 1.87 & 1.51 \\
\hline P8 & & 25 & & & & & & & 1.73 & & 87 & 1.41 \\
\hline P9 & & .06 & 40 & 0.91 & 1.47 & 1.06 & 1.47 & 0.99 & 1.47 & & 1.53 & 1.06 \\
\hline $\mathrm{P} 10$ & 67 & .05 & 53 & 1.06 & 1.53 & 1.06 & 1.47 & 83 & 1.47 & 2 & 1.40 & 0.91 \\
\hline P11 & & 16 & & 1.30 & 3 & 1.40 & & & 93 & & 93 & 1.44 \\
\hline $\mathrm{P} 12$ & & 0.99 & 2.40 & 1.50 & 1.93 & 1.16 & 2.20 & 1.52 & 2.13 & & 2.27 & 1.44 \\
\hline D13 & 67 & 1.18 & 1.67 & 1.18 & 1.73 & 1.28 & 2.07 & 1.58 & 2.20 & 1.78 & 2.20 & 1.78 \\
\hline P14 & 1.10 & 28 & & 1.28 & 57 & 1.18 & 1.87 & 1.55 & 1.80 & & 2.00 & 1.73 \\
\hline P15 & 2.00 & 1.25 & 1.87 & 1.25 & 1.80 & 1.26 & 1.87 & 1.46 & 1.93 & & 1.87 & 1.46 \\
\hline P16 & 1.73 & 1.16 & 1.80 & 1.26 & \begin{tabular}{|l|}
1.87 \\
\end{tabular} & 1.30 & 1.80 & 1.42 & 1.80 & 1.42 & 1.80 & 1.42 \\
\hline P17 & 2.40 & 1.12 & 2.20 & 1.01 & 2.27 & 1.16 & 1.73 & 1.33 & 1.73 & 33 & 1.80 & 1.42 \\
\hline P18 & 1.80 & 1.26 & 1.73 & 1.28 & 1.73 & 1.28 & 1.80 & 1.42 & 1.80 & 1.42 & 1.80 & 1.42 \\
\hline P19 & 2.07 & 1.28 & 1.93 & 1.16 & 1.80 & 0.94 & 1.47 & 1.06 & 1.47 & & 1.47 & 0.99 \\
\hline P20 & 1.40 & 0.83 & 1.53 & 0.99 & 1.40 & 0.83 & 1.33 & 0.90 & 1.40 & 1.06 & 1.33 & 0.90 \\
\hline $\mathrm{P} 21$ & 2.00 & 1.20 & 2.00 & 1.25 & 2.07 & 1.33 & 1.73 & 1.33 & 1.73 & & 1.73 & 1.39 \\
\hline $\mathrm{P} 22$ & 1.87 & 1.30 & 1.80 & 1.21 & 1.73 & 1.16 & 1.80 & 1.52 & 1.80 & 1.52 & 1.73 & 1.44 \\
\hline P23 & 1.87 & 0.99 & 1.80 & 1.01 & 2.07 & 1.39 & 1.87 & 1.55 & \begin{tabular}{|l|}
1.87 \\
\end{tabular} & 1.55 & 1.80 & 1.47 \\
\hline $\mathrm{P} 24$ & 1.40 & 0.91 & 1.33 & 0.72 & 1.33 & \begin{tabular}{|l|}
0.90 \\
\end{tabular} & 1.40 & 1.06 & 1.33 & 0.90 & 1.33 & 0.90 \\
\hline P25 & 1.60 & 1.06 & 1.60 & 1.06 & 1.67 & 1.18 & 1.73 & 1.39 & 1.73 & 1.39 & 1.73 & 1.44 \\
\hline Mean & 2.01 & & 1.93 & & \begin{tabular}{|l|}
1.87 \\
\end{tabular} & & 2.03 & & 1.96 & & \begin{tabular}{|l|}
1.99 \\
\end{tabular} & \\
\hline St.dev & 0.61 & & 0.47 & & 0.39 & & 0.55 & & 0.44 & & 0.47 & \\
\hline
\end{tabular}

StATISTIC DESCRIPTIVE OF MEAN ( $\mu$ ) AND StANDARD DEV. $(\Sigma)$ 
Based on the statistics mean and standard deviation of data collected from the respondent, as shown in Table IV, it could be seen that the statistics mean of frequency and severity between $1^{\text {st }}$ period, $2^{\text {nd }}$ period, and thi ${ }^{\text {rd }}$ period is not significantly different. The prominent value is only in some variables, as in variable P11.

\section{B. Analysis Frequency Index (FI), Severity Index (SI) and Risk Important Index (RII)}

Analysis of Frequency Index (FI) shows the probability of the emergence of risk variables that affect project performance. Calculation for FI and SI has used the formula as follow [12]:

$$
\begin{aligned}
& \text { Frequency Index, }(F I)=\frac{\sum_{i=1}^{\mathrm{A}} \mathrm{a}_{\mathrm{i}} \mathrm{n}_{\mathrm{i}}}{A \cdot \mathrm{N}} \\
& \text { Severity Index, }(\mathrm{SI})=\frac{\sum_{\mathrm{i}=1}^{\mathrm{A}} \mathrm{a}_{\mathrm{i}} \mathrm{n}_{\mathrm{i}}}{\mathrm{A} \cdot \mathrm{N}}
\end{aligned}
$$

Where $\mathrm{a}_{\mathrm{i}}$ is the constant expressing the weighting given to each response (in this research 1 for very low and up to 5 for very high of the frequency/the severity), $\mathrm{n}_{\mathrm{i}}$ Is the frequency of the response, $\mathrm{A}$ is the highest weight (in this research is 5 ), and $\mathrm{N}$ is the total number of responses (in this research is 15). The factor with the highest rank indicates that it has the maximum frequency/severity of occurrence, while the factor with the lowest rank indicates that it has the least frequency/severity of occurrence [12].

The Risk Important Index (RII) is an index value explaining the risk level in each risk variable, and this RII is influenced by the both of probability and severity for each variable. The Risk Important Index (RII) for each risk variable is analyzed using the formula (5).

$$
\text { Risk Important Index, }(R I I)=F I x S I
$$

Based on the Calculation of the Percentage of RII as shown in Table 6; it shows that P11 (Unofficial levies charges by bullies) is the most dominant risk variable (which ranks at the top) in all the review period. The percentage of RII of the P11 variable indicates a very significant value against other variables. This illustrates that these variables have a significant influence on the contractors working in the Aceh. As their opinion of excesses arising from the variable P11 (Unofficial levies charges by bullies):

- These variables could trigger other variables that will also impact on their reduced profits, such as security costs, high insurance costs for workers, high wage demands from workers, and loss of on-site material.

- Other risk-related effects, such as schedule delays, are threatened with the safety of the workers,

- Granting for the unofficial levies will be categorized as in assisting the criminal activity.

- The risk fee will not be reimbursed by the owner and could not be included in the quotation price

- Insurance agencies also refuse to provide collateral for unofficial levies.

- The nominal of unofficial levies is very high that could exceed the contractor's profits.

\begin{tabular}{|c|c|c|c|c|c|c|c|c|c|c|c|c|c|c|c|c|c|}
\hline & \multicolumn{4}{|c|}{$1^{\text {st }}$ Period } & \multirow{2}{*}{ 气 } & & \multicolumn{4}{|c|}{$2^{\text {nd }}$ Period } & \multirow{2}{*}{ 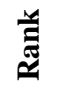 } & & \multicolumn{4}{|c|}{$3^{\text {rd }}$ Period } & \multirow{2}{*}{ 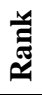 } \\
\hline & FI & SI & RII & \% RII & & & FI & SI & RII & $\%$ RII & & & FI & SI & RII & \%RII & \\
\hline $\mathrm{P} 11$ & 0.8533 & 0.7333 & 0.6258 & $100.0 \%$ & 1 & P11 & 0.6933 & 0.5867 & 0.4068 & $65.01 \%$ & 1 & P11 & 0.6667 & 0.5867 & 0.3911 & $62.51 \%$ & 1 \\
\hline P5 & 0.6000 & 0.5867 & 0.3520 & $56.26 \%$ & 2 & P5 & 0.4933 & 0.5600 & 0.2763 & $44.15 \%$ & 2 & P5 & 0.4267 & 0.5733 & 0.2446 & $39.09 \%$ & 2 \\
\hline P6 & 0.5733 & 0.5467 & 0.3134 & $50.09 \%$ & 3 & P6 & 0.5600 & 0.4933 & 0.2763 & $44.15 \%$ & 3 & P6 & 0.4533 & 0.5067 & 0.2297 & $6.71 \%$ & 3 \\
\hline P1 & 0.4533 & 0.5333 & 0.2418 & $38.63 \%$ & 4 & P1 & 0.4533 & 0.5333 & 0.2418 & $38.63 \%$ & 4 & P1 & 0.3600 & 0.5467 & 0.1968 & $31.45 \%$ & 4 \\
\hline $\mathrm{P} 12$ & 0.4267 & 0.4400 & 0.1877 & $30.00 \%$ & 5 & P12 & 0.4800 & 0.4267 & 0.2048 & $32.73 \%$ & 5 & $\mathrm{P} 4$ & 0.4000 & 0.4667 & 0.1867 & $29.83 \%$ & 5 \\
\hline P3 & 0.3600 & 0.5067 & 0.1824 & $29.15 \%$ & 6 & P3 & 0.3867 & 0.4533 & 0.1753 & $28.01 \%$ & 6 & $\mathrm{P} 3$ & 0.3733 & 0.4933 & 0.1842 & $29.43 \%$ & 6 \\
\hline P4 & 0.3867 & 0.4667 & 0.1804 & $28.84 \%$ & 7 & P2 & 0.3600 & 0.4800 & 0.1728 & $27.62 \%$ & 7 & P12 & 0.3867 & 0.4533 & 0.1753 & $28.01 \%$ & 7 \\
\hline P2 & 0.3467 & 0.4933 & 0.1710 & $27.33 \%$ & 8 & P4 & 0.3733 & 0.4533 & 0.1692 & $27.04 \%$ & 8 & P2 & 0.3600 & 0.4800 & 0.1728 & $27.62 \%$ & 8 \\
\hline P17 & 0.4800 & 0.3467 & 0.1664 & $26.60 \%$ & 9 & P17 & 0.4400 & 0.3467 & 0.1525 & $24.38 \%$ & 9 & P17 & 0.4533 & 0.3600 & 0.1632 & $26.08 \%$ & 9 \\
\hline P15 & 0.4000 & 0.3733 & 0.1493 & $23.86 \%$ & 10 & P13 & 0.3333 & 0.4400 & 0.1467 & $23.44 \%$ & 10 & P13 & 0.3467 & 0.4400 & .1525 & $24.38 \%$ & 10 \\
\hline P8 & 0.3733 & 0.3867 & 0.1444 & $23.07 \%$ & 11 & P15 & 0.3733 & 0.3867 & 0.1444 & $23.07 \%$ & 11 & P23 & 0.4133 & 0.3600 & 0.1488 & $23.78 \%$ & 11 \\
\hline $\mathrm{P} 23$ & 0.3733 & 0.3733 & 0.1394 & $22.27 \%$ & 12 & P21 & 0.4000 & 0.3467 & 0.1387 & $22.16 \%$ & 12 & P21 & 0.4133 & 0.3467 & 0.1433 & $22.90 \%$ & 12 \\
\hline $\mathrm{P} 21$ & 0.4000 & 0.3467 & 0.1387 & $22.16 \%$ & 13 & P23 & 0.3600 & 0.3733 & 0.1344 & $21.48 \%$ & 13 & P8 & 0.3600 & 0.3733 & 0.1344 & $21.48 \%$ & 13 \\
\hline P13 & 0.3333 & 0.4133 & 0.1378 & $22.01 \%$ & 14 & P16 & 0.3600 & 0.3600 & 0.1296 & $20.71 \%$ & 14 & P15 & 0.3600 & 0.3733 & .1344 & $21.48 \%$ & 14 \\
\hline P22 & 0.3733 & 0.3600 & 0.1344 & $21.48 \%$ & 15 & P22 & 0.3600 & 0.3600 & 296 & $20.71 \%$ & 15 & P16 & 0.3733 & 0.3600 & 1344 & $21.48 \%$ & 15 \\
\hline P18 & 0.3600 & 0.3600 & 0.1296 & $20.71 \%$ & 16 & P14 & 0.3467 & 0.3600 & 48 & $19.95 \%$ & 16 & P14 & 0.3333 & 0.4000 & 333 & $31 \%$ & 16 \\
\hline P14 & 0.3467 & 0.3733 & 0.1294 & $20.68 \%$ & 17 & P18 & 0.3467 & 0.3600 & 0.1248 & $19.95 \%$ & 17 & P7 & 0.3467 & 0.3733 & 0.1 & $68 \%$ & 17 \\
\hline P16 & 0.3467 & 0.3600 & 0.1248 & $19.95 \%$ & 18 & $\mathrm{P} 7$ & 0.3333 & 0.3600 & 0.1200 & $19.18 \%$ & 18 & P18 & 0.3467 & 0.3600 & 0.1248 & $19.95 \%$ & 18 \\
\hline P7 & 0.3333 & 0.3733 & 0.1244 & $19.88 \%$ & 19 & P8 & 0.3333 & 0.3467 & 0.1156 & $18.47 \%$ & 19 & P22 & 0.3467 & 0.3467 & 0.1202 & $19.21 \%$ & 19 \\
\hline P19 & 0.4133 & 0.2933 & 0.1212 & $19.37 \%$ & 20 & P19 & 0.3867 & 0.2933 & 0.1134 & $18.13 \%$ & 20 & P25 & 0.3333 & 0.3467 & 0.1156 & $18.47 \%$ & 20 \\
\hline P25 & 0.3200 & 0.3467 & 0.1109 & $17.73 \%$ & 21 & P25 & 0.3200 & 0.3467 & 0.1109 & $17.73 \%$ & 21 & P19 & 0.3600 & 0.2933 & 0.1056 & $16.87 \%$ & 21 \\
\hline $\mathrm{P} 10$ & 0.3333 & 0.2933 & 0.0978 & $15.62 \%$ & 22 & $\mathrm{P} 10$ & 0.3067 & 0.2933 & 0.0900 & $14.38 \%$ & 22 & P9 & 0.2933 & 0.3067 & 0.0900 & $14.38 \%$ & 22 \\
\hline P9 & 0.3067 & 0.2933 & 0.0900 & $14.38 \%$ & 23 & $\mathrm{P} 20$ & 0.3067 & 0.2800 & 0.0859 & $13.72 \%$ & 23 & P10 & 0.3067 & 0.2800 & 0.0859 & $13.72 \%$ & 23 \\
\hline P24 & 0.2800 & 0.2800 & 0.0784 & $12.53 \%$ & 24 & P9 & 0.2800 & 0.2933 & 0.0821 & $13.12 \%$ & 24 & $\mathrm{P} 20$ & 0.2800 & 0.2667 & 0.0747 & $11.93 \%$ & 24 \\
\hline P20 & 0.2800 & 0.2667 & 0.0747 & $11.93 \%$ & 25 & P24 & 0.2667 & 0.2667 & 0.0711 & $11.37 \%$ & 25 & P24 & 0.2667 & 0.2667 & 0.0711 & $11.37 \%$ & 25 \\
\hline
\end{tabular}

TABLE V

RESULt OF FREQUENCY INDEX (FI), SEVERITY INDEX (SI), RISK IMPORTANT INDEX (RII), AND RANK 
The reasons of the contractors are also reflected in the RII rank, as shown in Table V. The sequence of RII that relate that reasons are respectively $\mathbf{P 1 1}$ (Unofficial levies charges by bullies), P5 (Increased costs for safety and security in project areas), P6 (Increased labour costs due to increased wages), P12 (Contractors short of funds caused by the cost overrun on the project), and P3 (Overhead costs that exceed forecasts).

\section{Scoring System}

The Likert-items about Likert-scales [13] contains multiple items, and they are more reliable than single items. Likert-scales should be checked it reliability and in this research using Cronbach's alpha.

Likert-scale interval, as shown in Table VI, uses descriptive statistics. It can be applied to produce good analysis as well as correlation analysis, factor analysis, variance analysis if all conditions and assumptions are met. We use Likert-scale that consist of 5 items to measure the risk frequency, the risk severity, as shown in Table VI and Table VII. The frequency scales are based on the indications of the probability of the event could occur in life project span (scoring), as shown in Table VI. The severity scales are based on the indications of the profit loss assumption in the potential for risk occurs (scoring), as shown in Table VII.

TABLE VI

SCORING FOR THE RISK FREQUENCIES ASSESSMENT

\begin{tabular}{|c|c|c|c|}
\hline No & Risk Rating & The possibility of risk & Scoring \\
\hline 1 & $\begin{array}{c}\text { Occur } \\
\text { frequently }\end{array}$ & $\begin{array}{c}\text { the probability will happen } \geq \\
80 \% \text { in a project }\end{array}$ & FI $\geq 0.8$ \\
\hline 2 & $\begin{array}{c}\text { Recurrent but } \\
\text { not frequent }\end{array}$ & $\begin{array}{c}\text { the probability will happen } \\
\geq 60 \% \text { to }<80 \% \text { in a project }\end{array}$ & $0.6 \leq \mathrm{FI}<0.8$ \\
\hline 3 & $\begin{array}{c}\text { Could occur, } \\
\text { but uncommon }\end{array}$ & $\begin{array}{c}\text { the probability will happen } \\
\geq 40 \% \text { to }<60 \% \text { in a project }\end{array}$ & $0.4 \leq \mathrm{FI}<0.6$ \\
\hline 4 & Occurs rarely & $\begin{array}{c}\text { the probability will happen } \\
\geq 20 \% \text { to }<40 \% \text { in a project }\end{array}$ & $0.2 \leq \mathrm{FI}<0.4$ \\
\hline 5 & Almost never & $\begin{array}{r}\text { the probability will happen }< \\
20 \% \text { in a project }\end{array}$ & FI $<0.2$ \\
\hline
\end{tabular}

TABLE VII

SCORING For THE RISK SEVERITY ASSESSMENT

\begin{tabular}{|c|c|c|c|}
\hline No & $\begin{array}{c}\text { Risk } \\
\text { Rating }\end{array}$ & Impact of risk events & Scoring \\
\hline 1 & Severe & the profit loss $\geq 130 \%$ & $\mathrm{SI} \geq 0.80$ \\
\hline 2 & Major & the profit loss $\geq 100 \%$ to $<130 \%$ & $0.60 \leq \mathrm{SI}<0.80$ \\
\hline 3 & Moderate & the profit loss $\geq 70 \%$ to $<100 \%$ & $0.40 \leq \mathrm{SI}<0.60$ \\
\hline 4 & Minor & the profit loss $\geq 40 \%$ to $<70 \%$ & $0.2 \leq \mathrm{SI}<0.40$ \\
\hline 5 & $\begin{array}{l}\text { No } \\
\text { Significant }\end{array}$ & the profit loss $<40 \%$ & $\mathrm{SI}<0.20$ \\
\hline \multicolumn{4}{|c|}{ Potential for Risk to Occur } \\
\hline \multicolumn{4}{|c|}{ Severe : $\begin{array}{l}\text { Contractors are unable to continue the work due } \\
\text { to losses on profit over the maximum tolerance }\end{array}$} \\
\hline \multicolumn{4}{|c|}{ Major : Contractors incur huge losses. } \\
\hline \multicolumn{4}{|c|}{ Moderate : Contractors get a slight profit or a zero profit } \\
\hline \multirow{2}{*}{\multicolumn{2}{|c|}{$\begin{array}{ll}\text { Minor : } \\
\text { nificant: }\end{array}$}} & \multicolumn{2}{|c|}{ Contractors get a profit that could be considered. } \\
\hline & & Impact & \\
\hline
\end{tabular}

\section{Risk Important Index (RII) and Risk Matrix}

Risk Matrix, as a product of frequency and severity categories, can be applied in various organizations level. This matrix analysis can be used to increase the visibility of risks and to assist the manager in decision-making [18]. The Risk matrix scoring and the indicator, which have been generated from RII, is matrix $\{5 \times 5\}$ with four categories that are based on scale 0 to 1 of scale indicator, as shown in Table VIII.

Many other standard risk matrices in contexts, like USDoD (United States Department of Defense) [14], NASA (National Aeronautics and Space Administration) [15], [16], ISO (International Organization for Standardization) [17], individual project and organization can create their own risk matrix [18].

TABLE VIII

RISK MATRIX SCORING AND INDICATOR

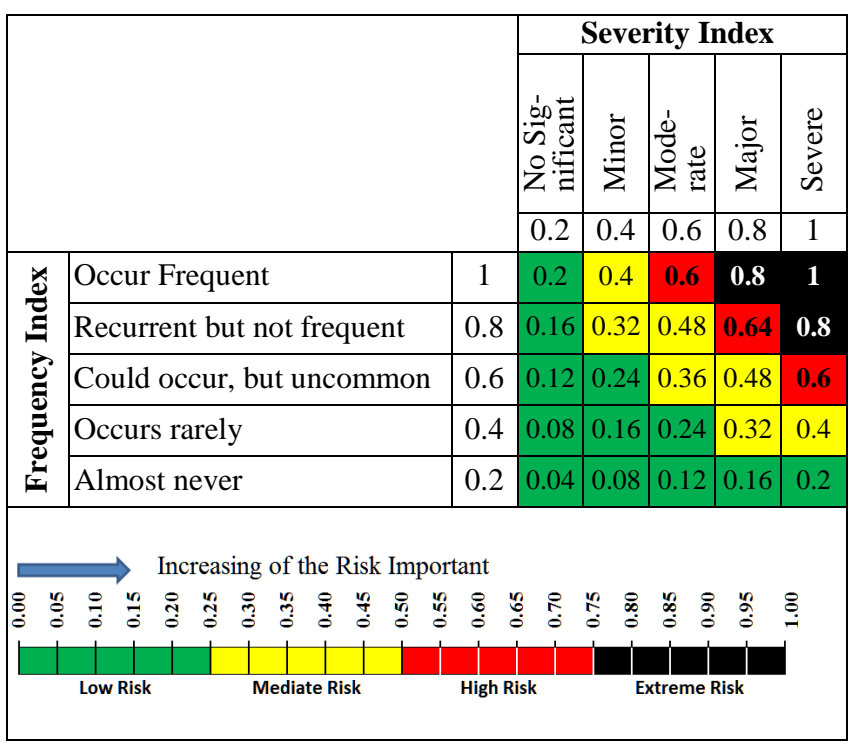

Table VIII is used to develop risk matrix assessment, as shown in Table IX. Qualitatively, the impact category of risk has been compiled, as shown in Table IX. The risk categories are divided into four quadrants of Low, Medium, High and Extreme.

TABLE IX

RISK MATRIX ANALYSIS

\begin{tabular}{|c|c|c|c|c|c|c|}
\hline & \multicolumn{5}{|c|}{ Risk Severity } \\
\hline & & 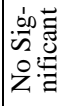 & $\stackrel{\grave{g}}{\vdots}$ & 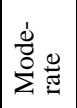 & 悥 & 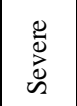 \\
\hline \multirow{5}{*}{ 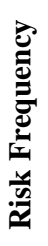 } & Occur Frequent & Low & Med. & High & Ext. & Ext. \\
\hline & Recurrent but not frequent & Low & Med. & Med. & High & Ext. \\
\hline & Could occur but uncommon & Low & Low & Med. & Med. & High \\
\hline & Occurs rarely & Low & Low & Low & Med. & Med. \\
\hline & Almost never & Low & Low & Low & Low & Low \\
\hline \multicolumn{7}{|c|}{ Extreme Risk:Termination of contract } \\
\hline \multicolumn{7}{|c|}{ High Risk: Project finish, get a huge loss } \\
\hline \multicolumn{7}{|c|}{ Medium Risk:|Project finish, get low profits } \\
\hline \multicolumn{7}{|c|}{ Low Risk: Project finish, profits acceptable } \\
\hline
\end{tabular}


TABLE X

QUALITATIVE RISKS ASSESSMENT

\begin{tabular}{|c|c|c|c|}
\hline \multirow{2}{*}{ Risk } & \multicolumn{3}{|c|}{ Qualitative Risk Assessment in each Periods } \\
\cline { 2 - 4 } & $\mathbf{1}^{\text {st }}$ Period & $\mathbf{2}^{\text {nd }}$ Period & $\mathbf{3}^{\text {rd }}$ Period \\
\hline P1 & Medium Risk & Medium Risk & Low Risk \\
\hline P2 & Low Risk & Low Risk & Low Risk \\
\hline P3 & Low Risk & Low Risk & Low Risk \\
\hline P4 & Low Risk & Low Risk & Medium Risk \\
\hline P5 & Medium Risk & Medium Risk & Medium Risk \\
\hline P6 & Medium Risk & Medium Risk & Medium Risk \\
\hline P7 & Low Risk & Low Risk & Low Risk \\
\hline P8 & Low Risk & Low Risk & Low Risk \\
\hline P9 & Low Risk & Low Risk & Low Risk \\
\hline P10 & Low Risk & Low Risk & Low Risk \\
\hline P11 & Extreme Risk & Medium Risk & Medium Risk \\
\hline P12 & Medium Risk & Medium Risk & Low Risk \\
\hline P13 & Low Risk & Low Risk & Low Risk \\
\hline P14 & Low Risk & Low Risk & Low Risk \\
\hline P15 & Low Risk & Low Risk & Low Risk \\
\hline P16 & Low Risk & Low Risk & Low Risk \\
\hline P17 & Low Risk & Low Risk & Low Risk \\
\hline P18 & Low Risk & Low Risk & Low Risk \\
\hline P19 & Low Risk & Low Risk & Low Risk \\
\hline P20 & Low Risk & Low Risk & Low Risk \\
\hline P21 & Low Risk & Low Risk & Low Risk \\
\hline P22 & Low Risk & Low Risk & Low Risk \\
\hline P23 & Low Risk & Low Risk & Low Risk \\
\hline P24 & Low Risk & Low Risk & Low Risk \\
\hline P25 & Low Risk & Low Risk & Low Risk \\
\hline & & & \\
\hline
\end{tabular}

Based on the risk matrix analysis we will conduct the assessment of-of 25 risk variables, as shown in Table X. Some of these variables indicate a decrease and some remain, while the rest is showing a decrease. The results of the risk matrix will conduct a significant test using statistics.

We will perform the ANOVA test to know whether any the significant difference between the 1 st period to the second period, second period to the third period, and first period to the third period. This is done because of variations in the data, although the assessment of the Statistics Mean is different. ANOVA test is done by comparing $P_{\text {value }}$ to significant level $\alpha_{5 \%}$. The rule as follow:

if $P_{\text {value }}>\alpha_{5 \%}$, then the variable is Not Difference significantly $(\mathbf{N d})$

\section{if $P_{\text {value }} \leq \alpha_{5 \%}$, then the variable is Difference significantly (D)}

The results of the ANOVA test are as shown in Table XI. In the table are shown $P_{\text {value }}$ for each variable that are compared across the three periods. Only the P11 variable indicates a significant decrease in risk from 1st period to the next period. We can conclude that P11 (Unofficial levies charges by bullies) is the most dominant project risk variable to other variables and has decreased from one period to the next.

TABLE XI

THE RESULT OF HYPOTHESIS BASED ON P-VALUE OF ANOVA

\begin{tabular}{|c|c|c|c|c|c|c|c|}
\hline \multirow{2}{*}{$\begin{array}{c}\text { Risk } \\
\text { Variables }\end{array}$} & \multicolumn{3}{|c|}{$\mathrm{P}$-value } & \multirow[b]{2}{*}{ 㒸 } & \multicolumn{3}{|c|}{ Result Hypothesis of each variable } \\
\hline & $\begin{array}{l}\text { 1st Period to } \\
\text { 2nd Period }\end{array}$ & $\begin{array}{l}\text { 2nd Period to } \\
\text { 3rd Period }\end{array}$ & $\begin{array}{c}\text { 1st Period to } \\
\text { 3rd Period }\end{array}$ & & $\begin{array}{l}\text { 1st Period to } \\
\text { 2nd Period }\end{array}$ & $\begin{array}{l}\text { 2nd Period to } \\
\text { 3rd Period }\end{array}$ & $\begin{array}{l}\text { 1st Period to } \\
\text { 3rd Period }\end{array}$ \\
\hline $\mathrm{P} 1$ & 0.9308 & 0.8496 & 0.7847 & 0.05 & $\mathrm{Nd}$ & $\mathrm{Nd}$ & $\mathrm{Nd}$ \\
\hline $\mathrm{P} 2$ & 0.9755 & 0.9759 & 0.9508 & 0.05 & $\mathrm{Nd}$ & $\mathrm{Nd}$ & $\mathrm{Nd}$ \\
\hline $\mathrm{P} 3$ & 0.8869 & 0.8516 & 0.9633 & 0.05 & $\mathrm{Nd}$ & $\mathrm{Nd}$ & $\mathrm{Nd}$ \\
\hline $\mathrm{P} 4$ & 0.8574 & 0.7824 & 0.9224 & 0.05 & $\mathrm{Nd}$ & $\mathrm{Nd}$ & $\mathrm{Nd}$ \\
\hline P5 & 0.4602 & 0.7588 & 0.3021 & 0.05 & $\mathrm{Nd}$ & $\mathrm{Nd}$ & $\mathrm{Nd}$ \\
\hline P6 & 0.6240 & 0.7183 & 0.4211 & 0.05 & $\mathrm{Nd}$ & $\mathrm{Nd}$ & $\mathrm{Nd}$ \\
\hline P7 & 0.9955 & 0.8512 & 0.8485 & 0.05 & $\mathrm{Nd}$ & $\mathrm{Nd}$ & $\mathrm{Nd}$ \\
\hline P8 & 0.5872 & 0.6313 & 0.9790 & 0.05 & $\mathrm{Nd}$ & $\mathrm{Nd}$ & $\mathrm{Nd}$ \\
\hline P9 & 0.8389 & 0.7901 & 0.9417 & 0.05 & $\mathrm{Nd}$ & $\mathrm{Nd}$ & $\mathrm{Nd}$ \\
\hline $\mathrm{P} 10$ & 0.9989 & 0.9373 & 0.9310 & 0.05 & $\mathrm{Nd}$ & $\mathrm{Nd}$ & $\mathrm{Nd}$ \\
\hline P11 & 0.0443 & 0.9603 & 0.0479 & 0.05 & $\mathrm{D}$ & $\mathrm{Nd}$ & $\mathrm{D}$ \\
\hline P12 & 0.9751 & 1.0000 & 0.9763 & 0.05 & $\mathrm{Nd}$ & $\mathrm{Nd}$ & $\mathrm{Nd}$ \\
\hline P13 & 0.8560 & 0.9057 & 0.7655 & 0.05 & $\mathrm{Nd}$ & $\mathrm{Nd}$ & $\mathrm{Nd}$ \\
\hline P14 & 0.9391 & 0.8807 & 0.9408 & 0.05 & $\mathrm{Nd}$ & $\mathrm{Nd}$ & $\mathrm{Nd}$ \\
\hline P15 & 1.0000 & 0.9179 & 0.9165 & 0.05 & $\mathrm{Nd}$ & $\mathrm{Nd}$ & $\mathrm{Nd}$ \\
\hline P16 & 0.9101 & 0.9778 & 0.9313 & 0.05 & $\mathrm{Nd}$ & $\mathrm{Nd}$ & $\mathrm{Nd}$ \\
\hline P17 & 0.8289 & 0.8306 & 1.0000 & 0.05 & $\mathrm{Nd}$ & $\mathrm{Nd}$ & $\mathrm{Nd}$ \\
\hline P18 & 0.9782 & 1.0000 & 0.9782 & 0.05 & $\mathrm{Nd}$ & $\mathrm{Nd}$ & $\mathrm{Nd}$ \\
\hline P19 & 0.8846 & 0.7645 & 0.6595 & 0.05 & $\mathrm{Nd}$ & $\mathrm{Nd}$ & $\mathrm{Nd}$ \\
\hline P20 & 0.7197 & 0.7197 & 0.9979 & 0.05 & $\mathrm{Nd}$ & $\mathrm{Nd}$ & $\mathrm{Nd}$ \\
\hline P21 & 0.9751 & 0.8630 & 0.8369 & 0.05 & $\mathrm{Nd}$ & $\mathrm{Nd}$ & $\mathrm{Nd}$ \\
\hline P22 & 0.9184 & 0.8939 & 0.8154 & 0.05 & $\mathrm{Nd}$ & $\mathrm{Nd}$ & $\mathrm{Nd}$ \\
\hline $\mathrm{P} 23$ & 0.9520 & 0.8627 & 0.9090 & 0.05 & $\mathrm{Nd}$ & $\mathrm{Nd}$ & $\mathrm{Nd}$ \\
\hline P24 & 0.7543 & 0.9206 & 0.8319 & 0.05 & $\mathrm{Nd}$ & $\mathrm{Nd}$ & $\mathrm{Nd}$ \\
\hline $\mathrm{P} 25$ & 0.9900 & 0.9287 & 0.9287 & 0.05 & $\mathrm{Nd}$ & $\mathrm{Nd}$ & $\mathrm{Nd}$ \\
\hline
\end{tabular}

Note: Nd as No Significant Different; $\mathbf{D}$ as Significant Different 
Based on the result of the assessment risk for each variable across in all the third periods, the P4 (Penalties for project delays) increases in the 3rd period and both P1 and P12 are a decrease in the $3 \mathrm{rd}$ period, as shown in Table X and on the contrary, the hypothesis analysis, as shown in Table XI. They conclude that P1, P4, and P12 are not different between the three periods. It proves that it will be important to test the hypothesis on the output of RII, as part of the qualitative risk assessment.

Our concern is that the variables P5, P6, and P11 in the context are greater than or equal to Medium risk in the three periods, as shown in Table X. The most dominant variables occur regarding frequency and severity, and Important is the variable Unofficial levies charges by bullies (P11). The variable P11 triggers both P5 and P6.

The contractors generally agree that all three periods have different risk characteristics and they assert that the period of political conflict (1st Period) is the most difficult time frame to carry out the project because it involves security and could even derail the project's goals. P11 (Unofficial levies charges by bullies) in the 1st Period is very high in Aceh [18], and the contractors prefer to reject the project, even though, is offered by the owner (This is a statement of concern about the high risk of conflict in Aceh that could affect the implementation of the project). The contractor will be ready to accept the project work if the P11 variable could be accommodated in the contract, as the responsibility of the owner [19]. The effect on cost is derived both of the internal and external factors. Risks of the external factor are the most avoided by contractors when working on construction projects. It is avoided due to the project manager cannot controlling and assessing the risk of the occurrences, and it is even time [20].

Variable P11 will trigger the emergence of P5 (safety and security in the project areas) which is also a Medium risk. While P6 (Increased labor costs due to increased wages) was triggered by the workers' safety reasons for the conflicting area. The labors do not want to work in a particular place that could also threaten the worker's safety [18]. They are willing to work if the labor's wage that given could compensate the risk they receive or the labors demand very high wages (This is the reason why we declare P5, P6 triggered by P11).

In the 2nd Period in Aceh, it was assumed that about 101,000 housing units need replacement, 95,000 units needed to be rehabilitated and most of the infrastructure had been destroyed [21]. Risk characteristic in the 2nd Period is the large scale of projects in large number that must be conducted in limited time to revitalization and rehabilitation of constructions by the contractors. In this 2 nd period, the risk of the P11 variables has decreased from the previous period. This decrease occurs on FI (as shown in Fig. 1), SI (as shown in Fig. 2), and on RII (as shown in Fig. 3), while in P5 and P6 variables are constant. These P5 and P6 variables do not follow the pattern of P11 (as shown in Fig. 3), which according to logic P5 and P6 should decrease in line with P11 (as the trigger variable). This may be possible because the problem of limited resources in the 2nd Period becomes another cause.

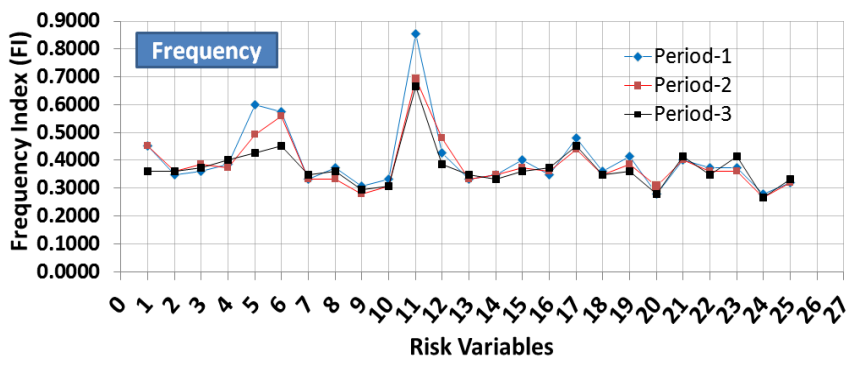

Fig. 1 Frequency Index (FI) in all three Periods

Another risk problem in the 2nd Period is many projects work that experiences the contract delay, or the projects could not be completed within the limit time span. This is due to overloading in carrying out many projects and exceeding contractor capacity. Indirectly, it has resulted in the loss of profit and even loss of contractor working capital, although this is not due to contractor fault. It is more because the system in Aceh has been paralyzed. The working contract is not for profit, but they are moved to be involved in the emergency response process in Aceh. Project risk is an uncertain event or condition that, if it occurs, has a positive/negative effect on project objectives such as scope, schedule, cost, and quality [22]. This is known as risk accepted as a sacrifice and willingness for humanitarian purposes. It is also done by foreign NGOs (NonGovernment Organizations) and other local NGOs.

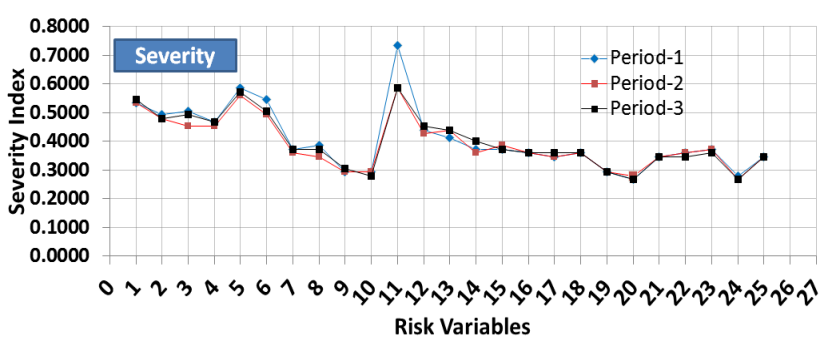

Fig. 2 Severity Index (SI) in all three Periods

We conclude that P5 (Increased costs for safety and security in project areas) and P6 (Increased labor costs due to increased wages) are not decreasing in line with the P11 (unofficial levies charges by bullies) pattern, as shown in Fig. 1 and Fig. 2, are not caused by political factors (like P11 in 1st Period) but is caused by the social, namely the lack and impoverishment of needs. This problem is common in disaster-affected areas.

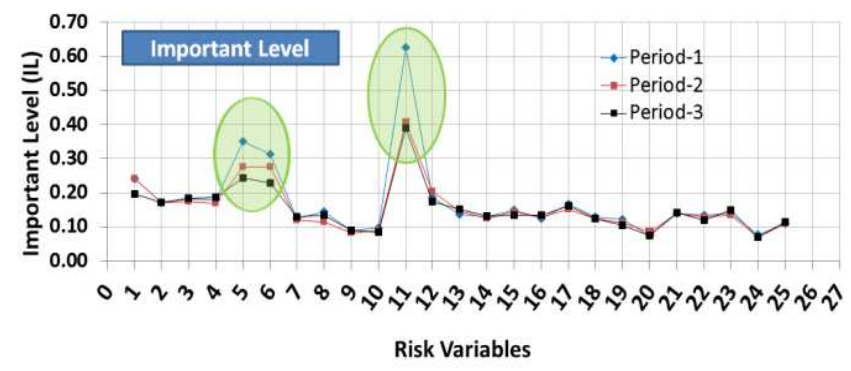

Fig. 3 Risk Important Index (RII) in all three Periods 
In this 3rd period, the risk pattern for that period is not triggered by 1 st period, but rather follows the precedence pattern (2nd period), as shown in Fig. 3.

\section{CONCLUSION}

In this research, we have researched the project risks occurring in Aceh on the three periods. This period is a perilous period from various aspects of life, including the construction aspect. The period is the political conflict (1st Period), the post-tsunami disaster (mitigation/2nd Period), and post-mitigation (3rd Period).

One of the most perceived risk variables by contractors is unofficial levies charges by bullies (P11). The high impact of these variables have on the Loss of Contractor's Profit, the contractor prefers to reject the project work offered to them. This P11 variable also has the potential to trigger other variables.

This research was conducted using hypothesis of the risk variables and combines it with risk assessment theory. This finding shows that hypotheses on the variables would have contributed to the change in the results of qualitative risk analysis, rather than using only RRI for risk-level analysis, as examples in $\mathrm{P} 1, \mathrm{P} 4$, and $\mathrm{P} 12$. The most important risk variable, unofficial levies charges by bullies (P11), is the most important variable of risk and it has dramatically decreased from the risk extreme to the Medium risk. This could be seen from the high number of contractors originating outside the province of Aceh who has followed the offer and carried out the work. Although should be supported by an understanding of the local geographic conditions [22].

The interpretation of the risk extreme in the 1st period is that the contractor will suffer huge losses and will even break the contract. However, in the next condition, the 2nd period and 3rd period, the contractor can carry out the work in Aceh, although the profit is not too large compared to other provinces in Indonesia. This research can be used as a recommendation for the Indonesian government, especially in Aceh, investors, and contractors in outside of Aceh.

\section{ACKNOWLEDGMENT}

The Authors appreciate to the parties in their contribution in this research; we would like thank Director in the contractors, the CEM Laboratory staff in Civil EngineeringSyiah Kuala University.

\section{REFERENCES}

[1] Fachrurrazi, S. Husin, Munirwansyah, and Husaini, "The Subcontractor Selection Practice using ANN-Multilayer," International Journal of Technology, vol. 8, no. 4, p. 761, Jul. 2017.
[2] S. Nazara, B. P. Resosudarmo, "Aceh-Nias Reconstruction and Rehabilitation: Progress and Challenges at the End of 2006, 2007,' ADB Institute Discussion Paper, No. 70, 2007.

[3] L. M. Khodeir and A. H. M. Mohamed, "Identifying the latest risk probabilities affecting construction projects in Egypt according to political and economic variables. From January 2011 to January 2013," HBRC J., vol. 11, no. 1, pp. 129-135, Apr. 2015.

[4] H. Abdul-Rahman, C. Wang, and F Sheik Mohamad, "Implementation of Risk Management in Malaysian Construction Industry: Case Studies". J. Constr. Eng. 2015.

[5] M. S. B. A. Abd El-Karim, O. A. Mosa El Nawawy, and A. M. Abdel-Alim, "Identification and assessment of risk factors affecting construction projects," HBRC J., Jun. 2015.

[6] Fachrurrazi, S. Husin, Tripoli, and Mubarak, "Neural Network for the Standard Unit Price of the Building Area," Procedia Engineering, vol. 171, pp. 282-293, 2017.

[7] Z. Sigmund and M. Radujković, "Risk Breakdown Structure for Construction Projects on Existing Buildings," Procedia - Soc. Behav. Sci., vol. 119, pp. 894-901, Mar. 2014.

[8] B. T. Saragiotto, T. P. Yamato, L. C. Hespanhol Junior, M. J Rainbow, I. S. Davis, and A. D. Lopes, "What are the main risk factors for running-related injuries?," Sports Medicine, vol. 44, no. 8. pp. 1153-1163, 2014.

[9] K. M. Baroang, M. Hellmuth, and P. Block, "Discussion Paper Identifying uncertainty and defining risk in the context of the WWDR-4" Perugia, Italy, (2009).

[10] G. M. Sullivan, "A primer on the validity of assessment instruments." J. Grad. Med. Educ., vol. 3, no. 2, pp. 119-20, Jun. 2011.

[11] M. M. Hossen, S. Kang, and J. Kim, "Construction schedule delay risk assessment by using combined AHP-RII methodology for an international NPP project," Nucl. Eng. Technol., vol. 47, no. 3, pp. 362-379, Apr. 2015.

[12] J. D. Brown, "Likert items and scales of measurement." Shiken: JALT Testing \& Evaluation SIG Newsletter 15, no. 1, pp. 10-14, (2011).

[13] DASDSE, "Risk, Issue, and Opportunity Management Guide for Defense Acquisition Programs," 2015.

[14] H. Dezfuli, A. Benjamin, C. Everett, G. Maggio, M. Stamatelatos, and R. Youngblood, "NASA Risk Management Handbook," no. November, p. 15, Nov. 2011.

[15] F. D. Control et al., "Guidelines for Risk Management Guidelines for Risk Management Rationale for Change,” pp. 1-40, 2014.

[16] L. Jodkowski, "Possibilities and Methods of Risk Assessment under ISO 9001 : 2015," vol. 3, no. 10, pp. 14-23, 2015.

[17] P. Zeccola, "Dividing disasters in Aceh, Indonesia: Separatist conflict and tsunami, human rights and humanitarianism," Disasters, vol. 35, no. 2, pp. 308-328, Apr. 2011.

[18] N. D. Long, S. Ogunlana, T. Quang, and K. C. Lam, "Large construction projects in developing countries: A case study from Vietnam," Int. J. Proj. Manag., vol. 22, no. 7, pp. 553-561, 2004.

[19] A. Giddens, "Risk and responsibility." The modern law review, vol. 62, no. 1, pp. 1-10, 1999.

[20] F. Steinberg, "Housing reconstruction and rehabilitation in Aceh and Nias, Indonesia-Rebuilding lives," Habitat Int., vol. 31, no. 1, pp. 150-166, 2007.

[21] K. H. Rose, "A Guide to the Project Management Body of Knowledge (PMBOK® Guide)-Fifth Edition.” Proj. Manag. J. 2013.

[22] Fachrurrazi, "Study of Unit Price for Competitive Bidding Based on CCI (Construction Cost Index) for Building" Int J Eng Res. 2016. 